\title{
Expression of gastrin and transforming growth factor- $\alpha$ during duct to islet cell differentiation in the pancreas of duct-ligated adult rats
}

\author{
R.N.Wang ${ }^{1}$, J.F.R ehfeld ${ }^{2}$, F.C.N ielsen ${ }^{2}$, G.K Klöppel ${ }^{1}$ \\ ${ }^{1}$ Department of Pathology, University of Kiel, Germany \\ ${ }^{2}$ Department of Clinical Biochemistry, Rigshospitalet, University of Copenhagen, Denmark
}

Summary In adult rats islet cell neogenesis can be stimulated by partial duct ligation. Duct to islet cell differentiation is thought to be regulated by growth factors such as gastrin and transforming growth factor- $\alpha$ (TGF $\alpha$ ). To test this hypothesis, we examined the expression of gastrin and TGF $\alpha$ at the mRNA and protein level in pancreatic tissue following partial duct ligation. Pancreatic specimens were investigated on days 3, 5, 7 and 14 after duct ligation by means of non-isotopic in situ hybridization, immunocytochemistry and Western blotting. Gastrin mRNA was strongly expressed in newly developed duct-like cell structures in the ligated tail portion of the pancreas before the period of pronounced islet cell neogenesis (days 5 and 7), and immunostaining for gastrin peptides was positive at days 5-7. In the non-ligated head portion and in control pancreases, gastrin was not expressed. Expression of TGF $\alpha$ was found to be increased in the ligated tail portion of the pancreas on day 3 and particularly on day 5 , while there was no enhanced signal in the non-ligated part. Western blotting revealed two different TGF $\alpha$ isoforms (18 $\mathrm{kDa}$ and $42 \mathrm{kDa}$ ) in the ligated tail part and three isoforms $(18 \mathrm{kDa}, 24 \mathrm{kDa}$ and $42 \mathrm{kDa})$ in the non-ligated head part and in untreated pancreases. The induction of gastrin and TGF $\alpha$ expression preceded the peak in the bromodeoxyuridine pulse labelling index of beta cells, known from a previous study to occur on day 7 . We conclude that pancreas duct ligation induces the overexpression of gastrin and TGF $\alpha$ in the first days following ligation. Since ductal cells are known to give rise to endocrine cells after duct ligation, gastrin and TGF $\alpha$ may play a role as growth factors in islet neogenesis. [Diabetologia (1997) 40: 887-893]

Keywords Pancreatic duct ligation, islet cell neogenesis, growth factors, gastrin, TGF $\alpha$.
A better understanding of the mechanisms that regulate beta cell growth and regeneration might be useful in the treatment of diabetes mellitus, the hope being that diabetes could be treated by either stimulating the growth of endogenous beta cells or increasing the number of exogenous (i.e. transplanted) beta

Received: 3 February 1997 and in revised form: 2 April 1997

Corresponding author: Professor G. Klöppel, Department of Pathology, University of Kiel, Michaelisstrasse 11, D-24105 Kiel, Germany

A bbreviations: TGF $\alpha$, Transforming growth factor- $\alpha$; DIG, digoxigenin; SSC, sodium chloride, sodium citrate; SDS, sodium dodecyl sulfate; TBST, Tris-buffered saline with Tween; BrdU, bromodeoxyuridine. cells [1-3]. Ligation of the pancreatic duct has been shown to induce islet cell neogenesis from duct cells in the adult rat pancreas $[4,5]$. Because islet cell neogenesis only occurs in the duct-ligated part of the pancreas, paracrine or autocrine regulation of the neogenetic process by growth factors can be assumed [5]. Little is known, however, about the nature and origin of the factors that regulate these events. Macrophages, a known source of growth stimulating cytokines [6], assemble rapidly after duct ligation in the pancreas in order to phagocytose apoptotic acinar cells $[7,8]$. The factors released by these macrophages may stimulate the proliferation of both stromal fibroblasts and duct cells [7-9]. One factor that is of particular interest in this process is transforming growth factor- $\alpha$ (TGF $\alpha)$, because it is not only 
produced by macrophages but is also expressed in pancreatic duct and islet cells $[10,11]$. Since the pancreas of TGF $\alpha$-overexpressing transgenic mice has been found to develop metaplastic ducts [12-14], it has been proposed that TGF $\alpha$ is a regulator of duct cell proliferation and differentiation [15]. Another factor that could influence the growth of the endocrine pancreas is gastrin, which is transiently expressed in the islets of the developing pancreas [1618], and therefore may affect islet cell neogenesis. Based on these observations, double transgenic mice were generated that overexpress TGF $\alpha$ in their exocrine pancreas and gastrin in their beta cells [15]. In these animals an increased islet mass (approximately twice that of control mice) was found, which was not noted in single transgenes that expressed either $\mathrm{TGF} \alpha$ or gastrin alone.

To test the hypothesis that growth factors such as gastrin and TGF $\alpha$ may be involved in endocrine cell growth and differentiation after pancreas duct ligation, we examined the expression of both factors in rat pancreatic tissue following partial duct ligation. Western blotting and immunocytochemical staining were applied to identify the protein levels of TGFa and in situ hybridization and immunocytochemistry to determine gastrin mRNA and protein expression. We now report that gastrin and TGF $\alpha$ are overexpressed in the pancreas of duct-ligated adult rats and that this overexpression occurs in ductal complexes.

\section{Materials and methods}

Experimental design and tissue processing. Male Wistar Hannover rats (Harlan Winkelmann GmbH, Hannover, Germany) were used. The animals weighed around $270 \mathrm{~g}$ and were 3 months old. Duct-ligated animals were anaesthetized with diethyl ether and operated on as described previously [5]. Normal (untreated) animals not subjected to any surgical procedure served as controls. Duct-ligated animals were killed 3, 5, 7 and 14 days after the operation, untreated rats were killed at the onset of the experiments. One hour prior to death the animals were injected intraperitoneally with bromodeoxyuridine (BrdU) (Sigma, St. Louis, Mo., USA) at a dose of $50 \mathrm{mg} /$ $\mathrm{kg}$ body weight. Eight to nine rats were investigated per time point and group. Pancreatic head and tail portions were dissected at the site of the duct ligature in the treated rats and at the corresponding site in the pancreas of untreated rats. For normal histology, immunocytochemistry and in situ hybridization, pieces of pancreas from three animals in each group were then either frozen in dry-ice-cooled isopentane or fixed in $4 \%$ paraformaldehyde overnight at room temperature. After fixation, the tissues were dehydrated and embedded in paraffin following routine procedures. Five to six pancreases from each group were frozen in liquid nitrogen and kept at $-80^{\circ} \mathrm{C}$ for Western blotting.

Immunocytochemistry. Acetone-fixed cryostat sections (5 $\mu \mathrm{m}$ thick) or deparaffinized sections ( $3 \mu \mathrm{m}$ thick) from control animals and from animals 3, 5, 7 and 14 days post-ligation were immunostained for gastrin and $\mathrm{TGF} \alpha$, respectively, using the $\mathrm{AB}$ complex method as described previously $[2,5,19,20]$.
The rabbit polyclonal anti-human gastrin antibody (kindly provided by Dr. J.J. Van der Haeghen) was used at a dilution of 1:6000. TGF $\alpha$ was detected with a mouse monoclonal anti-human TGF $\alpha$ Ab-2 antibody (Oncogene Science, Uniondale, N. Y., USA) diluted 1:20. BrdU was detected with a mouse monoclonal anti-BrdU antibody (Euro-Diagnostics, Apeldoorn, The Netherlands) diluted 1:10. Staining was visualized by incubation in DAB (3,3'-diaminobenzidine tetrahydrochloride, Sigma). The controls for immunostaining consisted of omission of the primary antibodies. In addition the antibodies against TGF $\alpha$ and gastrin were tested by absorption with excess human TGF $\alpha$ protein (Oncogene Science) and gastrin, respectively. These tests resulted in negative staining.

In situ hybridization. Paraformaldehyde-fixed pancreatic tissue from animals 3, 5, 7 and 14 days post-ligation was used for in situ hybridization. Control tissues were included. For detection of gastrin mRNA, an 87 nucleotide Hind III - Nco1 antisense DIG-RNA probe was used [21]. The DIG-labelled in situ hybridization method was essentially that of Komminoth [22]. Deparaffinized sections ( $3 \mu \mathrm{m}$ thick) were digested with $10 \mu \mathrm{g} / \mathrm{ml}$ proteinase K (Sigma) and washed with $0.1 \mathrm{~mol}$ Tris buffer, $\mathrm{pH} 7.4$, as previously reported [2]. After prehybridization for $3 \mathrm{~h}$, hybridization was initiated by adding the DIG-labelled gastrin RNA and $250 \mu \mathrm{g} / \mathrm{ml}$ yeast tRNA and $500 \mu \mathrm{g} / \mathrm{ml}$ herring sperm DNA (Sigma) for $16 \mathrm{~h}$ at $42^{\circ} \mathrm{C}$. The sections were then washed with graded concentrations of sodium chloride and sodium citrate (SSC) solution and incubated with alkaline phosphatase-conjugated polyclonal sheep anti-DIG antibody (diluted 1:1000). Sites of alkaline phosphatase activity were revealed by incubation in nitro blue tetrazolium and 5bromo-4-chloro-3-indolyl phosphate medium as chromogen to obtain a dark blue reaction. The specificity of the gastrin mRNA probe was tested by omission of the probe and pretreatment of tissue sections with RNase [2], which abolished all reactivity.

Western blot analysis. Proteins were extracted from fresh-frozen pancreas specimens from untreated animals and animals 3, 5, 7 and 14 days post-ligation. Samples were homogenized in lysine buffer containing $5 \%$ sodium dodecyl sulfate (SDS), $80 \mathrm{mmol} / \mathrm{l}$ Tris- $\mathrm{HCl}$ buffer ( $\mathrm{pH}$ 6.8), 5 mmol/l EDTA (pH 8.0) and $25 \mathrm{mmol} / \mathrm{l}$ phenylmethylsufonyl fluoride. After centrifugation at $3500 \mathrm{rev} / \mathrm{min}$ for $20 \mathrm{~min}$, the resulting supernatant was frozen. The protein concentration was measured by BCA protein assay kit (Pierce, Rockford, Ill., USA), using bovine serum albumin (fraction V) as standard. Proteins were separated by SDS-PAGE with a separating gel of $16.5 \%$, spacer gel of $10 \%$ and stacking gel of $4 \%$ according to the system of Laemmli [23]. Fifty $\mu \mathrm{g}$ of proteins were electrophoresed per lane and transferred to Hybond-PVDF (hydrophobic polyvinylidene difluoride; Amersham, Little Chalfont, UK) membrane with a semi-dry electroblotter. The transfer buffer contained $39 \mathrm{mmol} / \mathrm{l}$ glycine, $48 \mathrm{mmol} / \mathrm{l}$ Tris- $\mathrm{HCl}$ buffer, $0.04 \%$ SDS and $20 \%$ methanol. TGF $\alpha$ was identified with the ECL ${ }^{\mathrm{TM}}$ protein detection system (Amersham). The membranes were washed in Tris-buffered saline (20 mmol/l Tris, $150 \mathrm{mmol} / \mathrm{l} \mathrm{NaCl})$ containing $0.1 \%$ Tween 20 (TBST) and then blocked with TBST solution containing $5 \%$ non-fat dry milk. After blocking, immunoblotting was performed with the monoclonal anti-human TGF $\alpha$ Ab-1 antibody used for immunocytochemistry at a concentration of $5 \mu \mathrm{g} / \mathrm{ml}$ for $1 \mathrm{~h}$ at room temperature. The second antibody, a sheep anti-mouse Ig horseradish peroxidase antibody, was used at a dilution of 1:1000. Proteins were detected by ECL reagents for $1 \mathrm{~min}$ and exposed to BioMax MR film (Kodak, Rochester, N. Y., USA) for 5 min within 30 min after the reaction. 
Q uantitative estimation of TG F $\alpha$ protein. The TGF $\alpha$ protein levels in the pancreas of duct-ligated and untreated rats were quantified by densitometric analysis of autoradiograms of TGF $\alpha$ Western blots [24]. From each sample, $50 \mu \mathrm{g}$ of protein was separated by SDS-PAGE, and the density of the TGF $\alpha$ bands $(18 \mathrm{kDa})$ was scanned using computerized densitometry (Scanpack, Biometra, Göttingen, Germany) following a standardized protocol.

Statistical analysis. All data are expressed as mean \pm SEM. The difference between groups was evaluated by one-way analysis of variance and paired and unpaired Student's t-test.

\section{Results}

Pancreas morphology and B rdU labelling. The histological appearance and the BrdU labelling pattern of the pancreas tail after duct ligation have been described in detail by us [5] and others [7, 8]. Briefly, after 3 days the normal acinar cells were replaced by ductal structures and tubular complexes, which were embedded in an inflammatory infiltrate rich in macrophages. At days 5, 7 and 14 the normal acinar parenchyma had disappeared. Instead there were ductules and tubular complexes intimately associated with dilated ducts and islet cell clusters. There was marked interstitial inflammation. BrdU labelled particularly the cells of ducts and tubular complexes (Fig. 1).

G astrin expression. In the ligated tail portion of the pancreas, gastrin mRNA was strongly expressed in the cells of ductal complexes at day 3 post-ligation (Fig. 2A), while immunostaining for gastrin remained negative. On days 5, 7 and 14 post-ligation, the intensity of the hybridization signal for gastrin mRNA gradually decreased (Fig. 2B), whereas the immunostaining for gastrin was positive in the ductal complexes (Fig. 3). In the non-ligated head part of the pancreas and in untreated control pancreases, gastrin mRNA was not detected at either the mRNA (Fig. 2C) or protein levels.

TGF $\alpha$ expression. Weak immunocytochemical staining for TGF $\alpha$ was found in both the duct cells and endocrine cells of the non-ligated head part (Fig. 4A) and in the untreated pancreas of controls. No positive signal was observed in acinar cells and interstitial cells. Immunostaining for TGF $\alpha$ was increased in the tubular complexes and ducts of the ligated tail part at day 3 and even more at day 5 post-ligation, (Fig. 4B). After 7 days post-ligation, TGF $\alpha$ expression decreased.

To confirm the TGF $\alpha$ immunostaining, Western blots of pancreatic extracts were performed using the same monoclonal antibody to TGF $\alpha$ as for immunocytochemistry. TGF $\alpha$ isoforms of about $18 \mathrm{kDa}$ and $42 \mathrm{kDa}$ were detected in the ligated tail part of

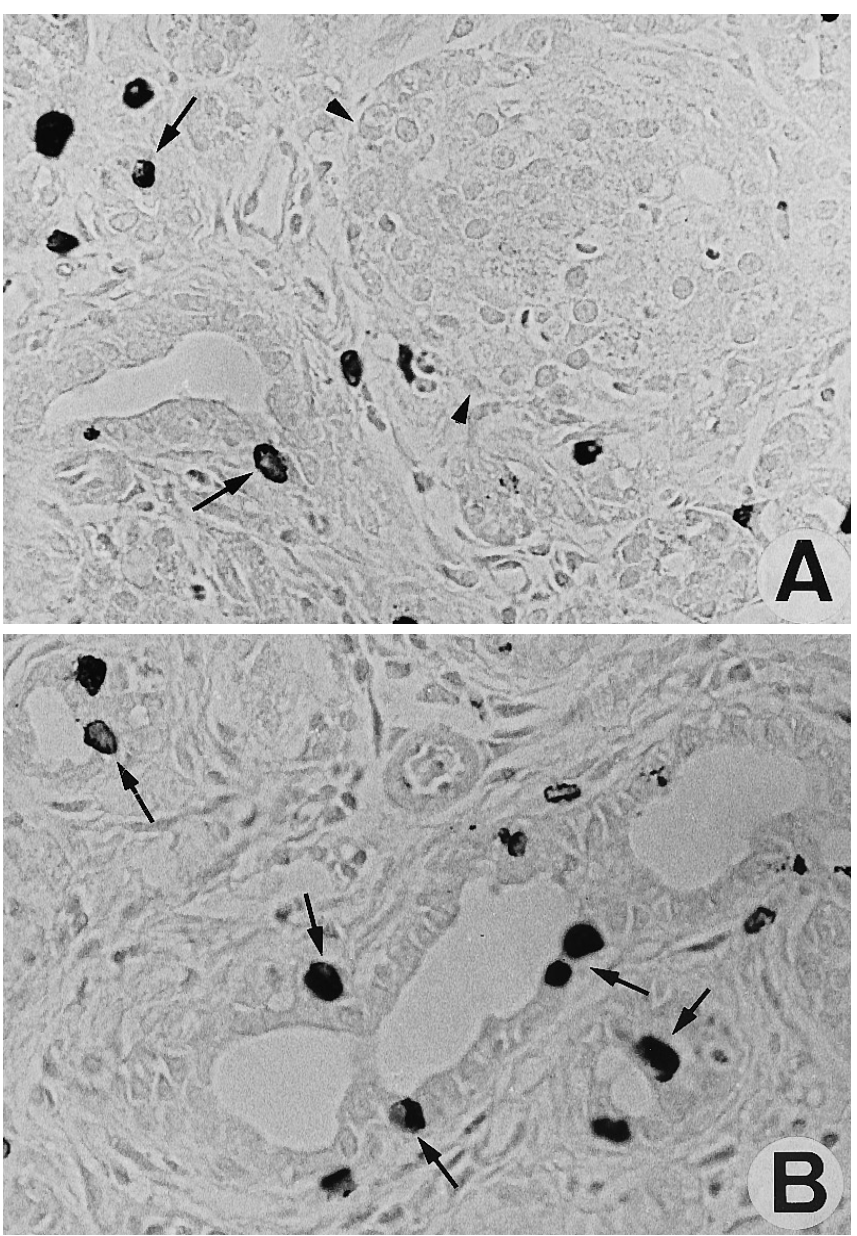

Fig. 1A , B . BrdU labelling on sections from the tail portion of the rat pancreas 3 (A) and 5 (B) days post-ligation. Numerous BrdU signals were found (arrows) in cells of ducts and tubular complexes. Arrowhead, islet. Original magnification $\times 400$

the pancreas, while isoforms of $18 \mathrm{kDa}, 24 \mathrm{kDa}$ and $42 \mathrm{kDa}$ were found in the non-ligated head part and the untreated pancreas (Fig. 5). Densitometric analysis of the autoradiograms demonstrated that TGF $\alpha$ $(18 \mathrm{kDa})$ protein levels were significantly increased in the ligated tail portion of the pancreas, compared to the unligated head portion, at days 3, 5, 7 and 14 post-ligation $\left(388 \pm 53^{\mathrm{u}}\right.$ ligated rats vs $176 \pm 28^{\mathrm{u}}$ untreated rats, $p<0.01)$. The highest values were noted at day 5 post-ligation. Subsequently they gradually decreased (Fig. 6). Densitometric analysis of all the Western blots $(18 \mathrm{kDa})$ indicated that TGF $\alpha$ levels were increased by a factor of 2.5 in the ligated tail of the pancreas at day 5, compared with the corresponding levels in the untreated pancreas.

\section{Discussion}

It is generally thought that islet cells in general and the pancreatic beta cells in particular have a limited proliferative potential in the postnatal period $[25$, 


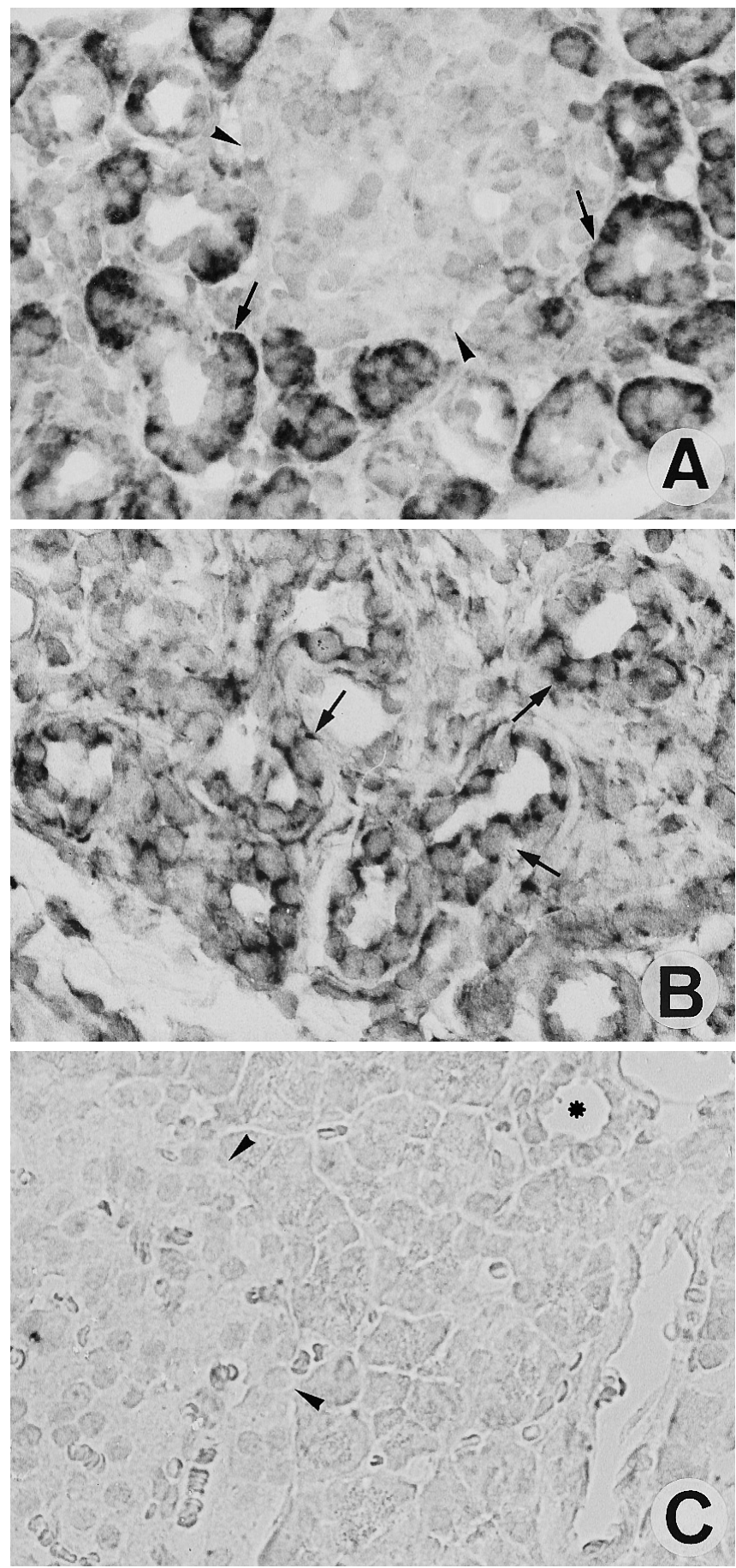

Fig. 2A - C. In situ hybridization for gastrin mRNA on sections from the tail portion of the rat pancreas, 3 (A) and 5 (B) days post-ligation. Cells of small ducts and tubular complexes show strong signals (A, B) for the mRNA probe (arrows). No signals are found in the head portion (C) of the pancreas. Arrowhead, islet; Asterisk, duct. Original magnification $\times 400$

26]. However, several experimental models have been developed that show that neoformation and replication of pancreatic endocrine cells are reactivated under certain conditions in adult animals [15, 27-30]. In this study we used the model of pancreas

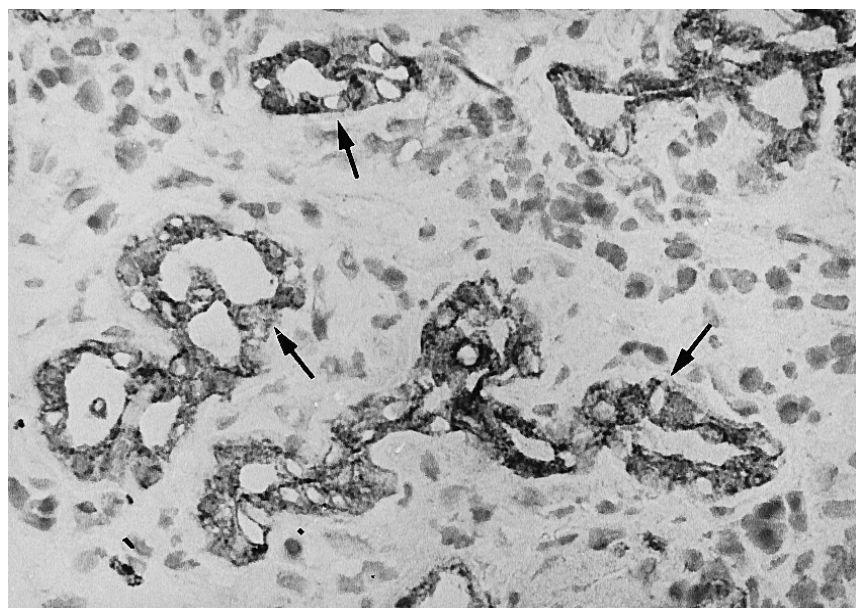

Fig. 3. Immunostaining for gastrin on an acetone-fixed cryostat section from the tail portion of the rat pancreas, 5 days post-ligation. Strong positivity of tubular complexes and ductules (arrows). Original magnification $\times 400$

duct ligation in the adult rat, in which we recently demonstrated islet cell neogenesis from adult pancreatic duct cells. It is likely that endocrine cytodifferentiation and cell proliferation in the pancreas involve both circulating factors and factors produced in the pancreatic tissue during the growth response. Among the factors implicated in this process are TGF $\beta 1$ [31], nicotinamide [32] hepatocyte growth factor/scatter factor [33], TGF $\alpha$ [15] and gastrin [15, 34]. Our study revealed that both gastrin and $\mathrm{TGF} \alpha$ are overexpressed in response to duct ligation in the ligated part of the adult rat pancreas. Increased immunostaining for proteins or peptides and increased gastrin mRNA expression were evident in cells of tubular complexes and pre-existing ducts, but not in the surrounding fibroblasts or connective tissue.

Gastrin appears to have a dual function as a hormone and as a trophic factor. As a hormone it stimulates gastric acid secretion by parietal cells indirectly via induced enterochromaffin like cell histamine release. Additionally it also stimulates the parietal cell receptor directly. As a trophic factor gastrin exerts a potent effect on the enterochromaffin like cell and, possibly, other intestinal cells as well [35]. Gastrin and the homologous cholecystokinin have been suggested to be responsible for increased $\left[{ }^{3} \mathrm{H}\right]$ thymidine labelling of pancreatic ductal and acinar cells in rats fed raw soya flour [36]. In the mammalian pancreas and particularly in the rat pancreas, gastrin is expressed both at the mRNA and the protein level [16-18] during late fetal gestation when cytodifferentiation into ductal, acinar and endocrine cells occurs [37], but disappears rapidly from the pancreas in the postnatal period. These findings suggest that pancreatic gastrin may play a role in pancreatic growth and development. In the duct-ligated adult rat pancreas, gastrin expression was strongest at day 3 , as 

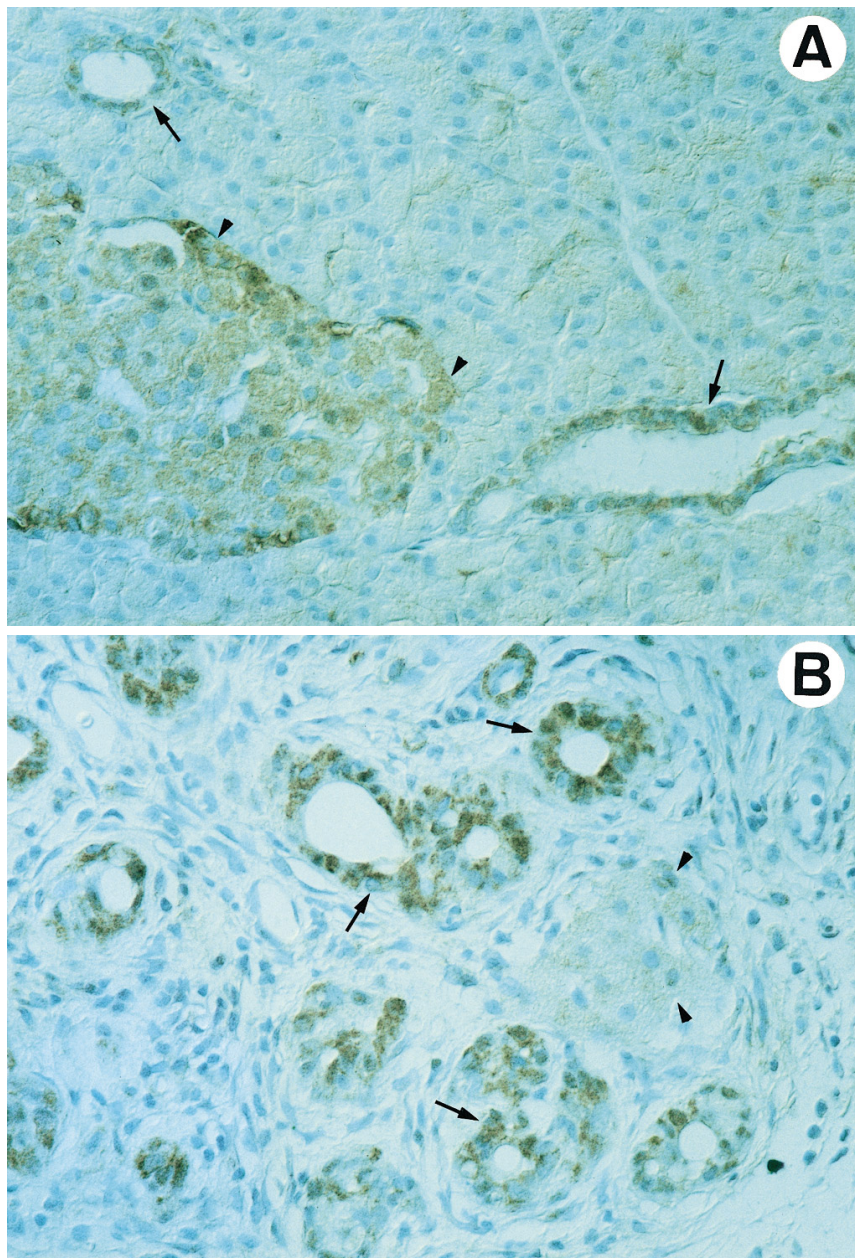

Fig. 4A, B. Immunocytochemical staining for $\mathrm{TGF} \alpha$ on sections from the head $(A)$ and tail portion of the rat pancreas (B), 5 days post-ligation of the pancreas tail. In the normal pancreas head (A) TGF $\alpha$ is expressed in islet cells (arrowheads) and duct cells (arrows). In the ligated pancreas tail (B) there is strong perinuclear staining in cells of ducts and tubular complexes (arrows) and weak labelling of islet cells (arrowheads). Original magnification $\times 400$

evidenced by in situ hybridization (mRNA), and at day 5 , as shown by immunocytochemistry (protein), and then declined. This coincided with the increased duct cell proliferation and also with the occurrence of newly formed beta and alpha cells observed in our previous study [5], suggesting that gastrin may mediate these regenerative changes. The mechanism by which gastrin is expressed in the duct-ligated rat pancreas is apparently also operative in humans. It has been found that pancreatic tissue from patients with duct-obstructing papilla Vateri tumours also expresses gastrin [38].

TGF $\alpha$ belongs to a small family of structurally related growth factors with mitogenic potential [39]. In particular, TGF $\alpha$ has been implicated in the proliferation of gastric mucosal cell types [40, 41]. In the pancreas, TGF $\alpha$, like gastrin, is also expressed in the late

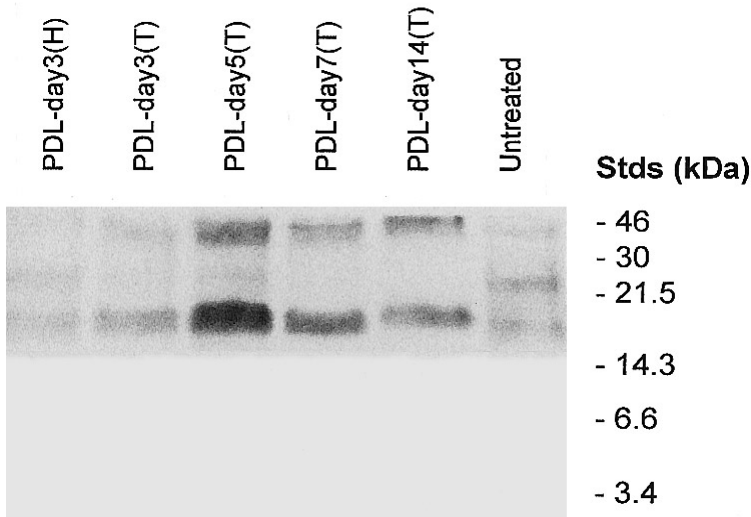

Fig. 5. TGF $\alpha$ Western blot. $50 \mu \mathrm{g}$ of protein from the various pancreas homogenates was loaded onto each lane. TGF $\alpha$ isoforms were detected by a monoclonal antibody to human TGF $\alpha$. Three isoforms of TGF $\alpha(18,24$ and $42 \mathrm{kDa})$ were present in the duct-ligated head portion and the untreated pancreas, and two isoforms (18 and $42 \mathrm{kDa}$ ) in the duct-ligated tail portion of the pancreas. Molecular weight markers (Stds) are shown on the right. PDL, duct-ligated group; $\mathrm{H}$, head portion; $\mathrm{T}$, tail portion

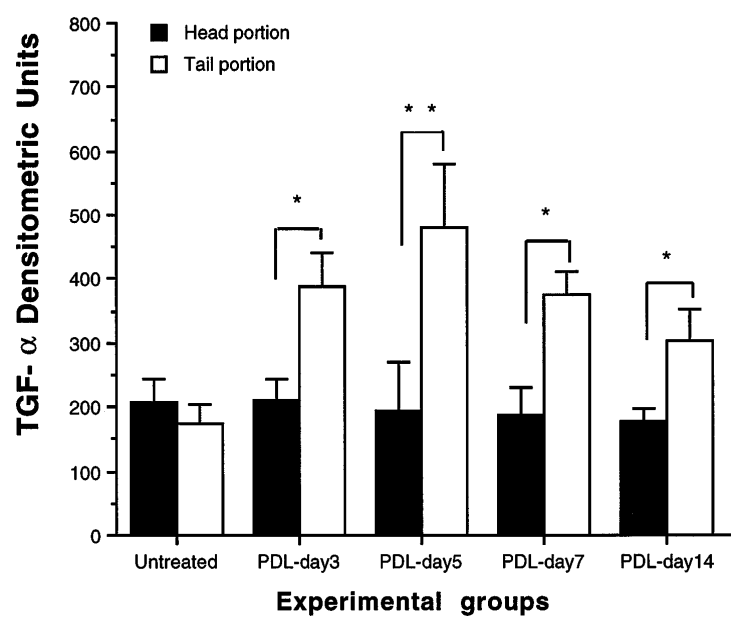

Fig. 6. Densitometric analysis of $\mathrm{TGF} \alpha$ (18 $\mathrm{kDa}$ isoform) Western blots. Data are expressed as mean \pm SEM of densitometric units $(n=6)$. Statistical analysis showed significant differences in the tail portion of the pancreas between untreated and duct-ligated rats $(p<0.01) . * p<0.05 ; * * p<0.01$. $\square$ head portion, $\square$ tail portion

fetal period, but, contrary to gastrin, continues to be present after birth [42]. During this period TGF $\alpha$ immunoreactivity is mainly found in islet and duct cells. TGF $\alpha$ exerts its effect through the epidermal growth factor receptor, which is known to be expressed by almost all cell types of the pancreas, but most abundantly by islet cells [42]. However, when duct cells are exposed to inflammation, they strongly express the epidermal growth factor receptor [43]. In the duct-ligated part of the adult rat pancreas we found substantially elevated TGF $\alpha$ protein expression in the cells of the tubular complexes and ducts as 
remodelling of the ligated pancreas parenchyma occurred. The intensity of the TGF $\alpha$ immunostaining and the densitometric analysis of TGF $\alpha$ Western blots indicated that TGF $\alpha$ was strongly amplified at days 3,5 and 7 post-ligation and later decreased. Western blot analysis revealed the expression of two $\mathrm{TGF} \alpha$ isoforms, one with $18 \mathrm{kDa}$ and the other with $42 \mathrm{kDa}$, in the ligated pancreas, which were also present, though weakly, in the non-ligated part of the pancreas and the untreated control pancreas. TGF $\alpha$ isoforms have been previously reported and may range from 5 to $45 \mathrm{kDa}$ [44-46]. In the case of the rat pancreas it seems that in particular the two isoforms, $18 \mathrm{kDa}$ and $42 \mathrm{kDa}$, are processed from pro-TGF $\alpha$ [47].

Although we did not perform any co-localization experiments, it was obvious from the labelling patterns that gastrin and TGF $\alpha$ were both expressed in cells with a ductal phenotype, which were shown in a previous study to contain cytokeratin $20[5,19]$. Since the precursor/stem cells that can give rise to new islet cells most likely belong to this cell compartment $[1,3$, 19, 48-51], we assume that gastrin and TGF $\alpha$ interact with the precursor/stem cells in an autocrine and/or paracrine fashion. Whether gastrin and TGF $\alpha$ interact with each other or with other growth factors or hormones, such as insulin-like growth factors 1 and 2 , growth hormone or hepatocyte growth factor/scatter factor [31, 52], is not known. It also remains to be elucidated whether the effects of both gastrin and TGF $\alpha$ are receptor mediated. Finally, it would be interesting to observe the expression of gastrin and TGF $\alpha$ for longer periods after duct ligation, to see whether the overexpression of both factors returns to normal once parenchymal remodelling has ceased.

In summary, we have shown that gastrin and TGF $\alpha$ are strongly expressed in pancreatic cells of the ductal phenotype with the capability to transform into endocrine cells in response to duct ligation. In contrast to the situation after partial $(90 \%)$ pancreatectomy, in which the development of both acinar and islet cells from ductal epithelium is found [49], pancreas duct ligation appears to stimulate only the proliferation and differentiation of endocrine cells.

A cknowledgements. We are grateful to Dr. U. Kellner for assistance with Western blotting, to Mr. M. Menke for helping us with the densitometric analysis and to Mrs. K. Dege for her helpful English corrections.

\section{References}

1. Rosenberg L, Vinik AI (1992) Trophic stimulation of the ductular-islet cell axis: a new approach to the treatment of diabetes. In: Vinik AI (ed) Pancreatic islet cell regeneration and growth. Plenum, New York, pp 95-104

2. Wang RN, Bouwens L, Klöppel G (1994) Beta-cell proliferation in normal and streptozotocin-treated newborn rats: site, dynamics and capacity. Diabetologia 37: 10881096

3. Bouwens L, Klöppel G (1996) Islet cell neogenesis in the pancreas. Virchows Arch 427: 553-560

4. Isaksson G, Ihse I, Lundquist I (1983) Influence of pancreatic duct ligation on endocrine and exocrine rat pancreas. Acta Physiol Scand 117: 281-286

5. Wang RN, Klöppel G, Bouwens L (1995) Duct- to islet-cell differentiation and islet growth in the pancreas of duct-ligated adult rats. Diabetologia 38: 1405-1411

6. Mosmann TR (1991) Cytokines, is there biological meaning? Curr Opin Immunol 3: 311-314

7. Yamaguchi Y, Matsuno K, Goto M, Ogawa M (1993) In situ kinetics of acinar, duct, and inflammatory cells in duct ligation-induced pancreatitis in rats. Gastroenterology 104: 1498-1506

8. Walker NI (1987) Ultrastructure of the rat pancreas after experimental duct ligation. I. The role of apoptosis and intraepithelial macrophages in acinar cell deletion. Am J Pathol 126: 439-451

9. Goto M, Matsuno K, Yamaguchi Y, Ezaki T, Ogawa M (1993) Proliferation kinetics of macrophage subpopulations in a rat experimental pancreatitis model. Arch Histol Cytol 56: 75-82

10. Korc M, Friess H, Yamanaka Y, Kobrin MS, Buchler M, Beger HG (1994) Chronic pancreatitis is associated with increased concentrations of epidermal growth factor receptor, transforming growth factor $\alpha$, and phospholipase $\mathrm{C} \gamma$. Gut 35: 1468-1473

11. Barton CM, Hall PA, Hughes CM, Gullick WJ, Lemoine NR (1991) Transforming growth factor alpha and epidermal growth factor in human pancreatic cancer. J Pathol 163: 111-116

12. Jhappan C, Stahle C, Harkins RN, Fausto N, Smith GH, Merlino GT (1990) TGF $\alpha$-overexpression in transgenic mice induces liver neoplasia and abnormal development of the mammary gland and pancreas. Cell 61: 1137-1146

13. Sandgren EP, Luetteke NC, Palmiter RD, Brinster RL, Lee DC (1990) Overexpression of TGF- $\alpha$ in transgenic mice: induction of epithelial hyperplasia, pancreatic metaplasia, and carcinoma of the breast. Cell 61: 1121-1135

14. Bockman DE, Merlino GT (1992) Cytological changes in the pancreas of transgenic mice overexpressing transforming growth factor- $\alpha$. Gastroenterology 103: 1883-1892

15. Wang TC, Bonner-Weir S, Oates PS et al. (1993) Pancreatic gastrin stimulates islet differentiation of transforming growth factor alpha-induced ductular precursor cells. J Clin Invest 92: 1349-1356

16. Larsson LI, Rehfeld JF, Håkanson R, Sundler F (1976) Pancreatic gastrin in foetal and neonatal rats. Nature 262: 609-610

17. Brand SJ, Fuller PJ (1989) Differential gastrin gene expression in rat gastrointestinal tract and pancreas during neonatal development. J Biol Chem 263: 5341-5347

18. Bardram L, Hilsted L, Rehfeld JF (1990) Progastrin expression in mammalian pancreas. Proc Natl Acad Sci USA 87: 298-302

19. Bouwens L, Wang RN, De Blay E, Pipeleers DG, Klöppel G (1994) Cytokeratins as markers of ductal cell differentiation and islet neogenesis in the neonatal rat pancreas. Diabetes 43: 1279-1283

20. Wang RN, Bouwens L, Klöppel G (1996) Beta-cell growth in adolescent and adult rats treated with streptozotocin during the neonatal period. Diabetologia 39: 548-557

21. Wiborg O, Bergund L, Boel E et al. (1984) Structure of a human gastrin gene. Proc Natl Acad Sci USA 81: 10671069 
22. Komminoth P (1992) Digoxigenin as an alternative probe labeling for in-situ hybridization. Diagn Mol Pathol 1: $142-150$

23. Laemmli UK (1970) Cleavage of structural proteins during the assembly of the head of bacteriophage T4. Nature 277: 680-685

24. Ogawa Y, Noma Y, Davalli AM, Wu YJ, Thorens B, Bonner-Weir S, Weir GC (1995) Loss of glucose-induced insulin secretion and Glut 2 expression in transplanted $\beta$-cells. Diabetes 44: 75-79

25. Hellerström C, Swenne I, Andersson A (1988) Islet cell replication and diabetes. In: Lefèbvre PJ, Pipeleers DG (eds) The pathology of the endocrine pancreas in diabetes. Springer, Berlin Heidelberg New York London Paris Tokyo, pp 141-170

26. Swenne I (1992) Pancreatic beta-cell growth and diabetes mellitus. Diabetologia 35: 193-201

27. Brockenbrough JS, Weir GC, Bonner-Weir S (1988) Discordance of exocrine and endocrine growth after $90 \%$ pancreatectomy in rats. Diabetes 37: 232-236

28. Rosenberg L, Duguid WP, Vinik AI (1989) The effect of cellophane wrapping of the pancreas in the Syrian golden hamster: autoradiographic observations. Pancreas 4: 31-37

29. Gu D, Lee MS, Krahl T, Sarvetnick N (1994) Transitional cells in the regenerating pancreas. Development 120: $1873-1881$

30. Rosenberg L, Vinik AI, Pittenger GL, Rafaeloff R, Duguid WP (1996) Islet-cell regeneration in the diabetic hamster pancreas with restoration of normoglycaemia can be induced by a local growth factor(s). Diabetologia 39: 256-262

31. Otokonski T, Beattie GM, Rubin JS, Lopez AD, Baird A, Hayek A (1994) Hepatocyte growth factor/scatter factor has insulinotropic activity in human fetal pancreatic cells. Diabetes 43: 947-953

32. Otokonski T, Beattie GM, Mally MI, Ricordi C, Hayek A (1993) Nicotinamide is a potent inducer of endocrine differentiation in cultured human fetal pancreatic cells. J Clin Invest 92: 1459-1466

33. Sanvito F, Herrera PL, Huarte J, Nichols A, Montesano R, Orci L, Vassalli JD (1994) TGF- $\beta$-1 influences the relative development of the exocrine and endocrine pancreas in vitro. Development 120: 3451-3462

34. Brand SJ, Andersen BN, Rehfeld JF (1984) Complete tyrosyl O-sulphation of gastrin in the neonatal rat pancreas. Nature 309: 456-458

35. Tielemans Y, Axelson J, Sundler F, Willems G, Håkanson R (1990) Serum gastrin concentration affects the self replication rate of the enterochromaffin like cells in the rat stomach. Gut 31: 274-278

36. Oates PS, Morgan RGH (1982) Pancreatic growth and cell turnover in the rat fed raw soya flour. Am J Pathol 108: 217-224

37. Pictet R, Rutter WJ (1972) Development of the embryonic endocrine pancreas. In: Geiger SR (ed) Handbook of physiology, section 7: Endocrinology. Waverley Press, Baltimore, pp 25-66
38. Bardram L (1990) Gastrin in non-neoplastic pancreatic tissue from patients with and without gastrinomas. Scand J Gastroenterol 25: 935-943

39. Derynck R (1992) The physiology of transforming growth factor alpha. Adv Cancer Res 58: 27-52

40. Bluth RF, Carpenter HA, Pittelkow MR, Page DL, Coffey RJ (1995) Immunolocalization of transforming growth factor- $\alpha$ in normal and diseased human gastric mucosa. Hum Pathol 26: 1333-1340

41. Tang LH, Modlin IM, Lawton GP, Kidd M, Chinery R (1996) The role of transforming growth factor $\alpha$ in the enterochromaffin-like cell tumor autonomy in an African rodent M astomys. Gastroenterology 111: 1212-1223

42. Hormi K, Lehy T (1994) Developmental expression of transforming growth factor- $\alpha$ and epidermal growth factor receptor proteins in the human pancreas and digestive tract. Cell Tiss Res 278: 439-450

43. Lemoine NR, Hughes CM, Barton CM et al. (1992) The epidermal growth factor receptor in human pancreatic cancer. J Pathol 166: 7-12

44. Russell WE, Dempsey PJ, Sitaric S, Peck AJ (1993) Transforming growth factor- $\alpha$ (TGF- $\alpha$ ) concentrations increase in regenerating rat liver: evidence for a delayed accumulation of mature TGF- $\alpha$. Endocrinology 133: 1731-1738

45. Humphreys-Beher MG, Macauley SP, Chegini $\mathrm{N}$ et al. (1994) Characterization of the synthesis and secretion of transforming growth factor- $\alpha$ from salivary glands and saliva. Endocrinology 134: 963-970

46. Vivekananda J, Lin A, Coalson JJ, King RJ (1994) Acute inflammatory injury in the lung precipitated by oxidant stress induces fibroblasts to synthesize and release transforming growth factor- $\alpha$. J Biol Chem 269: 25057-25061

47. Massagué J (1990) Transforming growth factor- $\alpha$, a model for membrane-anchored growth factors. J Biol Chem 265: 21393-21396

48. Teitelman G, Lee JK (1987) Cell lineage analysis of pancreatic islet cell development: glucagon and insulin cells arise from catecholaminergic precursors present in the pancreatic duct. Dev Biol 121: 454-466

49. Bonner-Weir S, Baxter LA, Schuppin GT, Smith FE (1993) A second pathway for regeneration of adult exocrine and endocrine pancreas. A possible recapitulation of embryonic development. Diabetes 42: 1715-1720

50. Rosenberg L (1995) In vivo cell transformation: neogenesis of beta cells from pancreatic ductal cells. Cell Transplant 4: 371-383

51. Kerr-Conte J, Pattou F, Lecomte-Houcke M, Xia YJ, Boilly B, Proye C, Lefèbvre J (1996) Ductal cyst formation in collagen-embedded adult human islet preparations. A means to the reproduction of nesidioblastosis in vitro. Diabetes 45: $1108-1114$

52. Welsh M, Mares J, Öberg C, Karlsson T (1993) Genetic factors of importance for $\beta$-cell proliferation. Diabetes Metab Rev 9: 25-36 